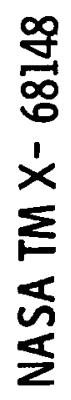

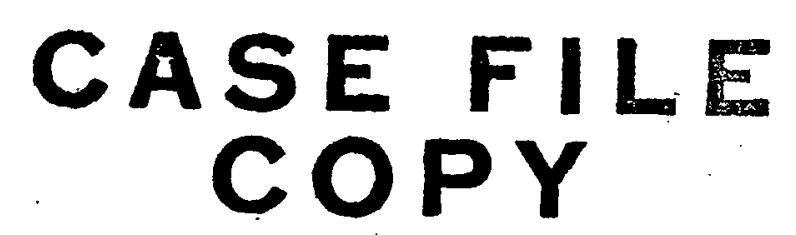

EXPLORATORY EVALUATION OF CERAMICS FOR AUTOMOBILE THERMAL REACTORS

by Phillip L. Stone and Charles P. Blankenship

Lewis Research Center

Cleveland, Ohio

TECHNICAL PAPER proposed for presentation at International Automotive Engineering Congress and Exposition sponsored by the Society of Automotive Engineers Detroit, Michigan, January 8-12, 1973 


\section{EXYLORATORY EVALUATION OF CERAMICS FOR AUTOMOBILE THERMAL REACTORS}

\section{BY PHILLIP L, STONE AND CHARLES P, BLANKENSHIP}

ABSTRACT

This report summarizes the results obtained in an exploratory evaluation of ceramics for automobile thermal reactors. Potential ceramic materials were evaluated in several reactor designs using both engine dynamometer and vehicle road tests. Silicon carbide contained in a corrugated metal support structure exhibited the best performance lasting over 800 hours in engine dynamometer tests and over $15,000 \mathrm{miles}(24,200 \mathrm{Km})$ of vehicle road tests. Reactors containing glass-ceramic components did not perform as well as silicon carbide. But the glass-ceramics still offer good potential for reactor use. The results of this study are considered to be a reasonable demonstration of the potential use of ceramics in thermal reactors. 


\section{EXPLORATORY EVALUATION OF CERAMICS FOR AUTOMOBILE THERMAL REACTORS}

\section{BY PHILLIP L, STONE AND CHARLES P, BLANKENSHIP}

\section{INTRODUCTION}

Ceramics offer excellent potential for use in automobile thermal reactors because of their inherent resistance to oxidation and relatively low cost. In addition, some ceramics can be used to higher temperatures than conventional metallic materials. An exploratory evaluation of ceramics for thermal reactor use is being conducted by the NASA-Lewis Research Center through both in-house and contracted studies. It is part of an automotive thermal reactor technology program being conducted in cooperation with the Environmental Protection Agency (1)*.

The major emphasis of our ceramic reactor studies has been focused on development of reactor design concepts to adequately support the relatively brittle ceramic components and prevent their failure by mechanical shock. Several reactor design concepts have been considered. Full-size reactors of the most promising designs have been subjected to either or both enginedynamometer tests and vehicle road tests. Ceramics for use in the exploratory thermal reactor tests have been selected primarily on the basis of resistance to thermal shock and relative ease of component manufacture. Reactor designs, candidate ceramic materials, and results from enginedynamometer and vehicle road tests of full-size reactors are described in this report.

*Numbers in parentheses designate references at end of paper. 
We want to emphasize that this exploratory technology program is directed primarily toward contributing material performance data and design concepts which may be useful to the designers of emission control systems. Potential problems of meeting emission standards with ceramic thermal reactors. (such as a higher thermal inertia than corresponding metallic reactors) are recognized. However, the emission control aspects of thermal reactors are beyond the scope of this exploratory program.

REACTOR MATERIALS, DESIGN, ANO FABRICATION

Materials Selection

Selection of the candidate ceramics for this program was based primarily on their resistance to thermal shock, strength, use-temperature, fabricability, and low cost. The ceramics selected for consideration, their typical properties, and source are listed in Table 1. Silicon carbide was one of the prime candidates. It is quite strong and has good thermal shock resistance due to its high thermal conductivity. Also, fabrication technology was adequate to manufacture the reactor components. Three varieties of silicon carbide were included. Both $\mathrm{KT}_{2}$ and Crystar represent commercial grades made by ceramic powder techniques. Graphite fiber reinforced sillicon carbide is an experimental ceramic-composite with a potential high temperature strength advantage over unreinforced silicon carbide.

Glass-ceramics have excellent resistance to thermal shock due to theill. low coefficient of thermal expansion. Two CER-VIT glass-ceramics were used in our evaluation on the basis of availability and ease of manufacturing reactor components. A different type of ceramic tested was Alcet which is 
a refractory material containing silicon nitride and aluminum. This material was selected on the basis of its good thermal shock resistance, fabricability, and resistance to oxidation.

All of the above materials were used in full-scale reactor tests. The other materials noted in Table 1 were selected for evaluation only in coupon screening tests. Fabrication technology for these materials was not developed sufficiently to assure manufacture of reactor components. However, with improved manufacturing techniques, these materials would warrant consideration on the basis of either lower cost or better resistance to thermal reactor environment. They include silica-calcium-aluminate, fused silica, mullites and $C P I$ (mullite and glass).

Reactor Design

The baseline reactor configuration for most of our ceramic reactors is shown schematically in figure 1. Design and operation of this reactor configuration are similar to the Dupont Type 11 circumferential flow reactor which has been shown to be effective in emissions control (2). Two concentric ceramic cylinders are used to form the combustion chamber. The inner cylinder is termed the reactor core and the outer cylinder is termed the liner. In our baseline design, the ceramic components including the inlet and exhaust ports are supported by thin-gage metal corrugations. The corrugation support structure acts like a spring to hold the ceramic components in place and absorb mechanical shock and vibration. other forms of support were considered such as high temperature, resilient insulation. But support systems of this type are more likely to be compacted by vibration resulting in loss of support for the ceramic components. 
The baseline reactor has the overall dimensions of 20 -inches $(51 \mathrm{~cm})$ in length and 5.5 -inches $(14.0 \mathrm{~cm})$ in diameter. Typical ceramic components were about $0.12-i n c h(0.30 \mathrm{~cm})$ thick. The metal corrugation structure was made from $0.006-i n c h(0.015 \mathrm{~cm})$ thick sheet. In the design shown in figure 1, the exhaust gas passes from the inner core through the slotted ends to the annulus and out the exhaust port. A similar design also evaluated had 14 holes about $0.6-$ inch $(1.5 \mathrm{~cm})$ in diameter in the wall of the inner core. The holes were located between the inlet ports and provided for exhaust gas flow from the inner core to the annulus and out the exhaust port.

In addition to the baseline reactor design, several other reactor configurations were designed and evaluated by Owens-lllinois, Inc. under a NASA contract. Their proprietary glass-ceramics, CER-VIT, were used in this development study. Their reactor designs are shown in figures 2,3 and 4. In designs $A$ and $B$, the reactor combustion chamber is similar to the baseline reactor except for the gas flow. The exhaust gas enters the outer annulus and passes to the reactor core through several holes in the core wall. Then the gas exhausts from the core through the outlet exhaust port. A closed-end honeycomb matrix surrounds the reactor liner. This honeycomb matrix provides for thermal insulation and support of the internal reactor structure. The honeycomb matrix is about $0.5-i n c h(1.2 \mathrm{~cm})$ thick and consists of honeycomb cells that have a web thickness of about $0.010-$ inch $(0.025 \mathrm{~cm})$ and a distance across the webs of about $0.065-i n c h$ $(0.170 \mathrm{~cm})$. The reactor core, liner, end pieces, and honeycomb matrix are 
cemented together to form a monolithic structure. Again, a corrugated metal structure is used to support the ceramic reactor components. Design $B$ is a modification of Design A with conical ends on the monolithic structure. Most of the support of this structure is provided by corrugations and metallic rings around the conical ends. Corrugations for radial support are reduced to about one-third that of Design $A$. In Design C, figure 4, the exhaust gas enters the central chamber and then passes through the open honeycomb matrix to the exhaust outlet port. Insulation and support is provided by the closed honeycomb matrix. Design $C$ is also a monolithic structure supported by metal corrugations.

\section{Reactor Fabrication}

Full-size reactors were fabricated for engine-dynamometer and vehicle road tests. The ceramics selected for full-size reactors of the baseline design are noted in Table 1. They included silicon carbide, graphite fiber reinforced silicon carbide, CER-VIT glass-ceramic, and Alcet. The ceramic components for the reactors were manufactured by the materials suppliers indicated in Table 1 using existing manufacturing techniques. Final assembly of the reactors was performed at NASA. Most of the reactors fabricated contained eleven ceramic parts: four inlet ports, an exhaust port, an inner core, an outer liner, and two caps and two rings for the reactor ends. The reactor end caps were loosely fitted to provide for inspection during test. A typical set of ceramic parts prior to assembly into a reactor housing is shown in figure 5. This particular set was made from a glass-ceramic and had several of the ceramic pieces cemented together thus 
reducing the basic number of parts from eleven to seven. The loose end cap provides for inspection during testing.

The metal corrugation structure used to support the ceramic components was made from $0.006-i n c h(0.015 \mathrm{~cm})$ thick Inconel 601 . This alloy offered the best combination of strength, oxidation resistance, and low cost of the alloy candidates considered. Relatively high temperatures $\left(>1600^{\circ} \mathrm{F}\right.$, $870^{\circ} \mathrm{C}$ ) were anticipated at the ceramic/metal corrugation interfaces. This high temperature would probably preclude the use of lower cost iron alloys except for the outer layer of the three-layer corrugation structure. The corrugation structure was made by spot-welding roll-corrugated strips $(\sim 0.8 \mathrm{in}, 2 \mathrm{~cm}$ wide) to a face sheet. Corrugation height was about 0.190inch $(0.478 \mathrm{~cm})$. Spacing between the corrugated strips was about 2 -inches $(5.5 \mathrm{~cm})$. Figure 6 shows the corrugation structure wrapped around a ceramic core and liner. Three layers of corrugation were used on these components. A single layer of corrugation was used to support the inlet and exhaust ports. Final assembly of a reactor is shown in figure 7 . The reactor housing was made from low carbon steel. During final assembly of the reactors, the spacing of the end corrugation was adjusted to provide a light pre-load on the ceramic components at operating temperatures. All of the reactors were thermocoupled to measure the gas temperature and the temperatures at various locations within the metal-corrugation structure. Fabrication of the reactor components for Designs $A, B$, and $C$ was accomplished using existing glass forming technology. Fabrication of the metal zorrugation supporting structure and the assembly of the reactor 
components was similar to that for the baseline design. However, the corrugation support was reduced to one or two layers.

A total of eight reactors of the baseline design and five of Design $A$, $B$, or $C$ were made for either engine-dynamometer tests or vehicle road tests as described in the following sections.

\section{TEST PROCEDURES \\ Engine-Dynamometer Tests}

The full-size ceramic reactors were subjected to an endurance test under simulated driving conditions on engine-dynamometer test stands. The tests were conducted by Teledyne-Continental Motors, Inc. under NASA contract. These test facilities, including reactor installation, operation of the V-8 engines, and control systems are described in (3). Figure 8 (a) shows schematically the endurance test cycle used. Part A simulates driving to work at about $35 \mathrm{mph}, 56 \mathrm{Km} / \mathrm{hr}\left(1550^{\circ} \mathrm{F}, 840^{\circ} \mathrm{C}\right.$ reactor temperature), with several stops and starts and a 10-minute drive on a freeway at $70 \mathrm{mph}, 113 \mathrm{~km} / \mathrm{hr}\left(1900^{\circ} \mathrm{F}, 1040^{\circ} \mathrm{C}\right.$ reactor temperature). Weekend shopping is simulated in Part $B$, and Part $C$ simulates a weekend trip consisting mostly of freeway driving at $70 \mathrm{mph}(113 \mathrm{~km} / \mathrm{hr})$. The total cycle consists of 32.5-hours of engine operation with the reactors at a peak temperature of about $1900^{\circ} \mathrm{F}\left(1040^{\circ} \mathrm{C}\right)$ for approximately 60 percent of the time. The cycle is repeated continuously in the endurance test.

The endurance test cycle provides extremely severe engine operation. For example, engine life is only about 900 to 1000 hours under these test conditions. Our goal was to achieve at least a 600-hour life with ceramic 
reactors. This would be comparable to the life achieved in some of the better metallic reactors using this test cycle (1).

Nonleaded gasoline was used in the tests since it was believed that some of the reactor materials might be subject to lead attack.

The ends of the baseline reactor had fittings installed to permit a relatively small amount of air cooling $\left(\sim 20 \mathrm{ft}^{3} / \mathrm{min}, 0.06 \mathrm{~m}^{3} / \mathrm{min}\right)$. This was done to prevent overheating of the corrugation structure by exhaust gas that would leak by the loosely fitted ceramic end pieces. As stated previously, the end pieces were loosely fitted for inspection purposes during tests. Air cooling of sealed reactors for use on an automobile should not be required. Inspection of the test reactors was accomplished by removing the ends and making a visual assessment of reactor condition. Normal inspections were made at approximately 200hour intervals.

Engine-dynamometer testing of the ceramic coupon samples noted in Table 1 was done at the NASA-Lewis Research Center. This facility is described in detail in (4). The coupons tested were about 0.12 to 0.19 inch $(0.32$ to $0.48 \mathrm{~cm})$ thick $\times 1$-inch $(2.54 \mathrm{~cm})$ wide $\times 2$-inches $(5 \mathrm{~cm})$ long. The ceramic coupons were placed on a test rack inside a metallic thermal reactor mounted on a $V-8$ engine. Location of the test coupons was maintained in line with the exhaust inlet ports of the reactor. Figure 8 (b) shows schematically the 17-minute test cycle used. This is similar to the coupon screening tests used to evaluate metallic materials (4). The test coupons were exposed to a minimum of $100 \mathrm{cycles}$ at a peak temper- 
ature of $1900^{\circ} \mathrm{F}\left(1040^{\circ} \mathrm{C}\right)$. Resistance to thermal shock, vibration, and oxidation were of primary concern in this brief screening test.

\section{Vehicle Road Tests}

Vehicle road tests were included in the program to provide a better measure of the capability of the reactor designs to prevent failure of the ceramic components from road shock and vibration. A motor-pool station wagon was modified to permit attachment of a thermal reactor on each bank of the V-8 engine. The modification included installation of an air injection system.

Two reactors of the baseline design were mounted on the vehicle for road tests--one reactor of silicon carbide and one reactor of the glassceramic. Figure 9 shows the engine compartment of the test vehicle with the reactors attached to the engine, Reactor core temperature, corrugation temperatures, and housing temperatures were continuously monitored during the road tests. Most of the road testing was accomplished by routine driving in and around the Cleveland area. Visual reactor inspections were conducted periodically by removing the reactor ends.

$$
\begin{aligned}
& \text { RESULTS AND DISCUSSION } \\
& \text { Reactor Temperature Profiles }
\end{aligned}
$$

Typical reactor temperature profiles obtained under the most severe conditions in the engine-dynamometer endurance test cycle are shown in figure 10 for both silicon carbide and glass-ceramic reactors of the baseline design. Reactor temperature profiles for Designs $A, B$, and $C$ under similar test conditions are shown in figure 11. Typical reactor tempera- 
ture profiles obtained in the vehicle road test at $70 \mathrm{mph}(113 \mathrm{~km} / \mathrm{hr})$ also are shown in figure 10.

In the engine dynamometer tests, peak reactor core temperatures of $1900^{\circ}$ to $2000^{\circ} \mathrm{F}\left(1040^{\circ}\right.$ to $\left.1090^{\circ} \mathrm{C}\right)$ resulted in temperatures ranging from $1625^{\circ}$ to $1725^{\circ} \mathrm{F}\left(880^{\circ}\right.$ to $\left.940^{\circ} \mathrm{C}\right)$ at the ceramic/metal corrugation interface for both silicon carbide and glass-ceramic reactors of the baseline design. Reactor end temperatures were considerably lower due to the air cooling. Reactor housing temperatures ranged from about $900^{\circ}$ to $1000^{\circ} \mathrm{F}\left(480^{\circ}\right.$ to $540^{\circ} \mathrm{C}$ ). These housing temperatures were considered excessively high with respect to reactor performance on a vehicle. Lower housing temperatures would be expected in vehicle operation due to a greater flow of air around the outside of reactors than was provided in the engine-dynamometer tests. Endurance test temperature profiles for Designs $A, B$, and $C$ show much lower temperatures at the ceramic/metal corrugation interfaces compared to the baseline design. This lower temperature resulted from the insulating characteristics of the honeycomb matrix and the greater distance of the metal corrugation from the hot sections of the reactor interior. However, the reactor housing temperatures of $825^{\circ}$ to $925^{\circ} \mathrm{F}\left(440^{\circ}\right.$ to $\left.500^{\circ} \mathrm{C}\right)$ were still considered to be excessively high compared to expected vehicle operation.

In the vehicle road tests, the maximum core temperature observed for both silicon carbide and the glass-ceramic reactors was about $1830^{\circ} \mathrm{F}$ $\left(1000^{\circ} \mathrm{C}\right)$. Most of the time, the reactor core temperatures ranged from $1650^{\circ}$ to $1750^{\circ} \mathrm{F}\left(900^{\circ}\right.$ to $\left.975^{\circ} \mathrm{C}\right)$. The lower reactor core temperatures than 
observed in the endurance test produced correspondingly lower ceramic/metal interface temperatures. Reactor housing temperatures were also lower due to the lower core temperature and to greater air cooling provided by the engine fan and vehicle motion. If the reactor core temperature had reached $1900^{\circ} \mathrm{F}\left(1040^{\circ} \mathrm{C}\right)$ as in the case of the engine-dynamometer tests, the housing temperatures would probably have been between $600^{\circ}$ and $700^{\circ} \mathrm{F}\left(320^{\circ}\right.$ and $\left.380^{\circ} \mathrm{C}\right)$. The temperatures of the silicon carbide reactor were lower overall than those of the glass-ceramic due to metal ducting installed in the vehicle. This ducting channeled a greater amount of air over the silicon carbide reactor for better cooling. Air cooling of the reactor ends was not used in the vehicle test reactors so the ceramic/metal corrugation interface temperatures at the ends and along the reactor length were similar. Engine-Dynamometer Tests Endurance tests. - Six baseline reactors and five reactors of Design $A, B$, or $C$ were endurance tested on the engine-dynamometer stands. The results are summarized in Table 11.

Silcon carbide reactors of the baseline design gave the best performance. Reactor $\mathrm{R}-2$ containing $\mathrm{KT}_{2}$ silicon carbide has lasted over 800 hours exceeding the test goal of 600 hours. The periodic inspections of $R-2$ have shown no signs of erosion or degradation. All components are in good condition and the tests are being continued. Reactor R-3 lasted nearly 600 hours even though the silicon carbide liner contained a hairline crack almost entirely around the circumference at the start of the test. The test was terminated when the crack opened sufficiently to cause overheat- 
ing of the corrugation structure. The ceramic parts from $R-3$ showed no evidence of erosion or chemical attack. A slight weight gain of 0.1 to 0.2 percent was noted probably indicating some oxidation of uncombined silicon.

The endurance test of the Crystar silicon carbide reactor was inconclusive. Excessive leakage of exhaust gas by the loose end caps caused overheating of the end corrugations and housing. None of the silicon carbide components failed although the test was of short duration ( $\sim 110$ hours). Modification of the end cap design is required in order to obtain a better evaluation of this material. We believe the Crystar has the capability to perform as well as the $\mathrm{KT}_{2}$ material.

Reactor R-4 containing graphite-reinforced silicon carbide failed in about 190 hours of testing. The primary failure was located at the reactor ends, but all of the components exhibited appreciable erosion and porosity. Most of the reactor components lost about 6 to 8 percent of their original weight. It appeared that the graphite fiber structure was not adequately coated with silicon carbide and oxidized during exposure to the exhaust gas environment. This led to the general degradation of the reactor components. Thus, improved manufacturing techniques are required to assure protection of the fiber structure in order for this material to perform satisfactorily in a thermal reactor application.

Reactor R-l containing the Alcet ceramic failed in less than 15 hours of testing. Failure resulted from excessive loss of aluminum from the ceramic. The free aluminum severely degraded the corrugation structure 
resulting in loss of support for the ceramic components. Improved heat treating procedures to assure stabilization of the Alcet material and/or better control of the composition are required before this material can be considered for reactor use.

Glass-ceramic reactors of both the baseline design and Designs $A$, $B$, and $C$ failed in less than 330 hours. However, we believe that this relatively short life is mostly attributable to reactor housing temperature problems rather than material limitations. From the analysis of all the failed reactors, we conclude that the primary problem was associated with the great difference in thermal expansion between the ceramic and metallic support components. With the nil thermal expansion of the glass-ceramic, and the higher than anticipated reactor housing temperatures, contact between the ceramic and the expanding metal support structure could not be maintained at temperature. Preloading the support structure to assure contact at temperature could not be accomplished without permanently deforming the corrugations. Under the cyclic test conditions, the unsupported glassceramic was not strong enough to withstand the mechanical vibration from the test engines and thus it failed. None of the glass-ceramics evaluated showed evidence of chemical degradation.

These results indicate that the use of glass-ceramics requires either close control of the reactor housing temperature or perhaps an improved design to assure that contact between the ceramic and the support structure is maintained. Air cooling the corrugations or a redesign to move the metal support structure away from the high temperature areas should be 
considered. The latter might be accomplished by attaching two or more ceramic ribs to the body of the ceramic using the corrugation support in the cooler areas of the ribs. Lower reactor housing temperatures would be obtained by placing insulation between the housing and the ceramic body.

Ceramic coupon tests. - The results of the coupon testing program are given in Table 111 . The variation in the number of test cycles is due to the influence of concurrent testing on the other bank of the engine. A one-to-one quantitative comparison of all materials is thus not possible, but clear trends are seen. The two silicon carbide specimens gained weight. This is consistent with the data obtained from the endurance tests of silicon carbide reactors. The graphite fiber-reinforced silicon carbide material lost a significant amount of weight which is in agreement with the full-size reactor test of this material. Most, if not all, of the glass-ceramic weight loss appeared to be due to chipping during disassembly from the test rack. The Alcet, the silica/calcium aluminate, and the CPI materials displayed mechanical strength problems as shown by their inability to complete even a 100-cycle test. The fused silica and the two mullites appeared to have good potential for reactor use based on the limited screening tests of these materials.

\section{Vehicle Road Tests}

The station wagon has been driven approximately 15,000 miles $(24,200$ $\mathrm{Km})$ with the silicon carbide reactor attached and approximately 12,000 miles $(19,300 \mathrm{~km})$ with the glass-ceramic reactor attached. Operating confidence was obtained first with the silicon carbide reactor prior to 
installation of the glass-ceramic reactor. Visual inspections of the reactors have been made at approximately $2000-\mathrm{mile}(3200 \mathrm{Km})$ intervals by removing the reactor ends. The reactors have shown no signs of degradation or incipient failure. The maximum reactor housing temperature observed in these tests was $500^{\circ} \mathrm{F}\left(260^{\circ} \mathrm{C}\right)$ for the glass-ceramic reactor. This probably explains in part why the glass-ceramic reactor has survived the vehicle road tests while its close counterpart, reactor $R-5$, failed the engine-dynamometer test.

Overall, the vehicle road tests were successful in demonstrating the potential use of ceramics components in a thermal reactor. Ample support of the ceramic components was provided by the metal corrugation structure. The reactors survived mechanical shock from both rough roads and engine vibration coupled with thermal cyclic operation. Road shock and engine vibration in the vehicle road tests were considered to be representative of normal driving conditions including freeway driving at high speeds as well as city driving in sub-zero weather.

While the engine dynamometer tests were more severe in terms of rapid thermal cycling and peak reactor temperatures, the vehicle road tests provided a major test of the reactor design and support structure in terms of resistance to mechanical shock. From the design aspect, the reactor cores (17.5-in, $44.5 \mathrm{~cm}$ in length and supported only at the ends) were considered to be most vulnerable to failure. But they have performed well, and their end-tab supports have shown no signs of chipping or abrasion. Continued vehicle road tests of the ceramic reactors are planned. But more exten- 
sive vehicle road tests than can be accomplished in this exploratory program will be required to fully demonstrate the use of ceramics in thermal reactors.

\section{CONCLUDING REMARKS}

From the results of this exploratory study, several ceramic materials appear to be good candidates for use in thermal reactors. Silicon carbide exhibited the best performance of the ceramics evaluated. Excellent containment of the relatively brittle silicon carbide components was provided by a corrugated metal support structure in both engine-dynamometer tests for over 800 hours and vehicle road tests for 15,000 miles $(24,200 \mathrm{~km})$. These tests are being continued. It is possible that an improved metalcorrugation support design may be required to reduce peak metal temperatures at the ceramic/metal interface. This would be an important factor should reactor core temperatures exceed the nominal $1900^{\circ} \mathrm{F}\left(1040^{\circ} \mathrm{C}\right)$ peak temperature used in this evaluation study. Existing manufacturing technology appears to be adequate for the fabrication of the relatively simple silicon carbide components used in this study. More complex geometries may be required in improved reactor designs for effective emission control. Thus, consideration should be given to the development of improved manufacturing techniques to fabricate more complex geometries.

We believe that glass-ceramics also offer potential for reactor use even though they did not perform as well as silicon carbide in our enginedynamometer tests. The low strength of the glass-ceramics at $1900^{\circ} \mathrm{F}$ $\left(1040^{\circ} \mathrm{C}\right)$ and the difficulty in maintaining contact with the metal support 
structure probably contributed to the poor performance of the glassceramics in the engine-dynamometer tests. In the less severe vehicle road tests (in terms of peak temperatures and thermal cycling), no difference was noted in the performance of either silicon carbide or the glassceramic. The reactor housing temperatures were lower in the vehicle road tests than in the engine-dynamometer tests (about $400^{\circ} \mathrm{F}, 200^{\circ} \mathrm{C}$ ). With the lower housing temperature, contact between the glass-ceramic and the metal support structure could be maintained. Thus, the use of glassceramics will require either close control of the reactor housing temperature or perhaps an improved reactor design to assure that contact between the ceramic and the support structure is maintained.

Compared to silicon carbide, the glass-ceramics have an advantage in the manufacture of complex reactor geometries since well established glass manufacturing technology can be used. Also, glass-ceramics offer potential for lower costs. But silicon carbide is stronger at reactor operating temperatures, and it has a higher over-temperature capability (at least $400^{\circ} \mathrm{F}, 200^{\circ} \mathrm{C}$ ) than glass-ceramics.

Other ceramics that warrant consideration for reactor use include fused-silica and high temperature mullites. Their potential for lower cost and ease of component manufacture should be considered in future ceramic reactor studies.

Future studies should be directed toward definition of reactor design requirements for emission control. Once this is established, trade-offs of the advantages of the potential ceramics could be more readily assessed in selecting the best candidate ceramic for reactor use. 
18

REFERENCES

1. C. P. Blankenship and R. R. Hubbard: Status Report on the NASA-EPA Thermal Reactor Technology Program. NASA TM X-68010, January 1972.

2. E. N. Cantwell, I. T. Rosenlund, W. J. Barth, F. L. Kinnear, and S. W. Ross: A Progress Report on the Development of Exhaust Manifold Reactors. Paper 690139 presented at SAE International Automotive Engineering Conference, Detroit, Michigan, January 1969.

3. R. E. Oldrieve: Evaluation of Some Candidate Materials for Automobile Thermal Reactors in Engine-Dynamometer Screening Tests - Interim Report. NASA TM X-67970. December 1971.

4. R. E. Oldrieve: Exploratory Screening Tests of Several Alloys and Coatings for Automobile Thermal Reactors. NASA TM X-67984, December 1971. 
TABLE I: CANDIDATE CERAMICS FOR THERMAL REACTORS AND TYPICAL PROPERTIES

\begin{tabular}{|c|c|c|c|c|c|c|c|c|c|c|c|c|}
\hline \multirow{3}{*}{ CERAMIC } & \multirow{2}{*}{\multicolumn{2}{|c|}{$\begin{array}{c}\text { COEFFICIENT } \\
\text { OF THERMAL } \\
\text { EXPANSION, X10-6 }\end{array}$}} & \multirow{2}{*}{\multicolumn{2}{|c|}{$\begin{array}{l}\text { THERMAL } \\
\text { CONDUCTIVITY }\end{array}$}} & \multicolumn{4}{|c|}{ MODULUS OF RUPTURE } & \multirow{2}{*}{\multicolumn{2}{|c|}{$\begin{array}{l}\text { MAXIMUM USE } \\
\text { TEMPERATURE }\end{array}$}} & \multirow{3}{*}{$\begin{array}{c}\text { DENSITY } \\
\text { G/CC }\end{array}$} & \multirow{3}{*}{$\begin{array}{l}\text { MATERIAL } \\
\text { PRODUCER }\end{array}$} \\
\hline & & & & & \multicolumn{2}{|c|}{ TEMPERATURE } & \multicolumn{2}{|r|}{ MOR } & & & & \\
\hline & $\mathrm{in} / \mathrm{in} /{ }^{\circ} \mathrm{F}$ & $\mathrm{cm} / \mathrm{cm} /{ }^{\circ} \mathrm{C}$ & $h r-f t^{2}-\cdot F$ & $\begin{array}{c}\mathrm{Cal}-\mathrm{cm} \\
\mathrm{hr}-\mathrm{cm}^{2}-{ }^{\circ} \mathrm{C}\end{array}$ & ${ }^{\circ} \mathbf{F}$ & ${ }^{\circ} \mathrm{C}$ & ks j & $M N / m^{2}$ & ${ }^{\circ} \mathbf{F}$ & ${ }^{\circ} \mathrm{C}$ & & \\
\hline \multicolumn{13}{|l|}{ SILICON CARBIDE } \\
\hline $\mathrm{KT}_{2}(1)$ & 2.8 & 5.0 & 215 & 266 & 2200 & 1200 & $18 \div 21$ & $124-145$ & 3000 & 1650 & 2.8 & Carborundum Company \\
\hline CRYSTAR $(1)$ & 2.7 & 4.9 & 145 & 180 & $\begin{array}{r}70 \\
2700\end{array}$ & $\begin{array}{r}20 \\
1480\end{array}$ & $\begin{array}{l}14-18 \\
18-22\end{array}$ & $\begin{array}{r}97-124 \\
124-152\end{array}$ & 3200 & 1760 & 2.6 & Norton Company \\
\hline $\begin{array}{l}\text { Graphite Fiber } \\
\text { Reinforced (i) }\end{array}$ & - & - & - & - & 70 & 20 & 14 & 97 & 2300 & 1260 & 2.5 & Fansteel, Inc. \\
\hline \multicolumn{13}{|l|}{ GLASS CERAMICS } \\
\hline CERVIT C-126(3) & 0.4 & 0.7 & 11.6 & 14.4 & $\begin{array}{r}70 \\
1900\end{array}$ & $\begin{array}{r}20 \\
1040\end{array}$ & $\begin{array}{c}30-35 \\
4-5\end{array}$ & $\begin{array}{c}207-242 \\
28-35\end{array}$ & 2000 & 1090 & 2.5 & Owens-Illinois Inc. \\
\hline CERVIT $C-129^{(1)}$ & 0.1 & 0.2 & 10.5 & 13.0 & $\begin{array}{r}70 \\
1900 \\
\end{array}$ & $\begin{array}{r}20 \\
1040 \\
\end{array}$ & $\begin{array}{c}10-14 \\
10\end{array}$ & $\begin{array}{c}69-97 \\
69 \\
\end{array}$ & 2100 & 1200 & 2.5 & Owens-111inois, Iac. \\
\hline ALCET $(A 1-S i-N)^{(1)}$ & 3.5 & 6.3 & 240 & 299 & $\begin{array}{r}70 \\
1500 \\
\end{array}$ & $\begin{array}{r}20 \\
820 \\
\end{array}$ & $\begin{array}{r}25 \\
3.5 \\
\end{array}$ & $\begin{array}{r}172 \\
24 \\
\end{array}$ & 3000 & 1650 & 2.6 & Remington Arms, Company \\
\hline $\begin{array}{l}\text { SILICAVCALCIUM } \\
\text { ALUMINATE }(2) \\
\end{array}$ & 0.45 & 0.81 & 2.0 & 2.5 & - & - & - & - & 3000 & 1650 & 1.8 & Bell-Ae rosystems, Inc. \\
\hline FUSED SILICA (2) & 0.7 & 1.3 & 1.2 & 1.5 & - & - & - & - & 2100 & 1150 & 2.2 & Owens-Corning Fiberglas 00 \\
\hline \multicolumn{13}{|l|}{ MULLITE } \\
\hline$R-21^{(2)}$ & 3.1 & 5.5 & - & - & 70 & 20 & 4.8 & 33 & 2650 & 1450 & - & Electrlcal Refractories Co \\
\hline$B-47^{(2)}$ & 2.4 & 4.3 & - & - & 70 & 20 & 2.7 & 19 & 2250 & 1230 & - & Electrical Refractories Co \\
\hline $\begin{array}{l}\text { CPI (mullit } \\
\quad+g \text { lass) }\end{array}$ & 3.0 & 5.4 & 1.8 & 2.2 & 70 & 20 & 2.5 & 17 & 2000 & 1090 & 0.4 & Grumman Aerospace Inc. \\
\hline
\end{tabular}

(1) Full-size reactor and coupon test

(2) Coupon test only

(3) Reactor test only 
TABLE II. SUMMARY OF FULL SIZE REACTOR ENDURANCE TESTS ON ENGINE-DYNAMOMETER

\begin{tabular}{|c|c|c|c|c|}
\hline $\begin{array}{l}\text { REACTOR } \\
\text { NUMBER }\end{array}$ & CERAMIC MATERIAL" & $\begin{array}{l}\text { DESIGN } \\
\text { TYPE }\end{array}$ & $\begin{array}{l}\text { HOURS } \\
\text { IN TEST }\end{array}$ & RESULTS OF VISUAL EXAMINATIONS \\
\hline$R-2$ & silicon carbide $-\mathrm{KT}_{2}$ & Baseline & $800+$ & $\begin{array}{l}\text { No deleterious effects observed---continuing } \\
\text { test. }\end{array}$ \\
\hline$R-3$ & Silicon carbide $-\mathrm{KT}_{2}$ & Baseline & 570 & $\begin{array}{l}\text { Circumferertial crack in ceramic outer liner } \\
\text { (present from beginning) opened causing. } \\
\text { housing overheating. }\end{array}$ \\
\hline$R-11$ & Silicon carbide - CRYSTAR & Baseline & 110 & $\begin{array}{l}\text { Excessive exhaust gas leakage at reactor } \\
\text { ends causing corrugation and housing over- } \\
\text { heating. }\end{array}$ \\
\hline$R-4$ & $\begin{array}{l}\text { Graphite Fiber } \\
\text { Reinforced Silicon carbide }\end{array}$ & Baseline & 190 & $\begin{array}{l}\text { Excessive graphite loss }(6-8 \text { weight per- } \\
\text { cent) leading to part deterioration. }\end{array}$ \\
\hline$R-1$ & ALCET: $(A I-S i-N)$ & Baseline & 15 & $\begin{array}{l}\text { Excessive loss of aluminum leading to part } \\
\text { and corrugation deterioration. }\end{array}$ \\
\hline$R-5$ & $\begin{array}{l}\text { Glass-ceramic } \\
\text { CERVIT C }-126\end{array}$ & Baseline & 165 & $\begin{array}{l}\text { Inadequate corrugation support at tempera- } \\
\text { ture. Thermal cycling and engine vibration } \\
\text { led to cracked ceramic parts. }\end{array}$ \\
\hline$R-6$ & $\begin{array}{l}\text { Glass-ceramic } \\
\text { CERVIT. } c-129\end{array}$ & Type $C$ & 30 & $\ldots \ldots$ \\
\hline$R-7$ & & Type A & 35 & \\
\hline$R-10$ & & Type A & 330 & \\
\hline$R-12$ & & Type A & 255 & \\
\hline$R-13$ & & Type B & 85 & \\
\hline
\end{tabular}


TABLE III. SUMMARY OF CERAMIC COUPON TEST DATA

\begin{tabular}{|c|c|c|c|}
\hline CERAMIC & $\begin{array}{l}\text { NO. TEST } \\
\text { CYCLES }\end{array}$ & $\begin{array}{l}\text { WEIGHT } \\
\text { CHANGE，\% }\end{array}$ & RESULTS OF VISUAL EXAMINATION \\
\hline \multicolumn{4}{|l|}{ SILICON CARBIDE } \\
\hline $\mathrm{KT}_{2}$ & 140 & +0.15 & No cracks or chipping \\
\hline CRYSTAR & 100 & +0.19 & No cracks or chipping \\
\hline Graphite fiber reinforced & 140 & -4.7 & Minor chipping on edges. \\
\hline \multicolumn{4}{|l|}{ GLASS-CERAMIC } \\
\hline$c-129$ & 100 & -2.5 & Chipping in disassembly from test rack. \\
\hline ALCET & 100 & - & Specimens cracked \\
\hline SILICA/CALCIUM ALUMINATE & 100 & - & Specimens cracked \\
\hline FUSED SILICA & 100 & -0.11 & No cracks or chipping \\
\hline \multicolumn{4}{|l|}{ MULLITE } \\
\hline$R-21$ & 150 & +1.0 & No cracks or chipping \\
\hline$B-47$ & 150 & +1.0 & No cracks or chipping \\
\hline CPI & 150 & - & Specimens cracked \\
\hline
\end{tabular}




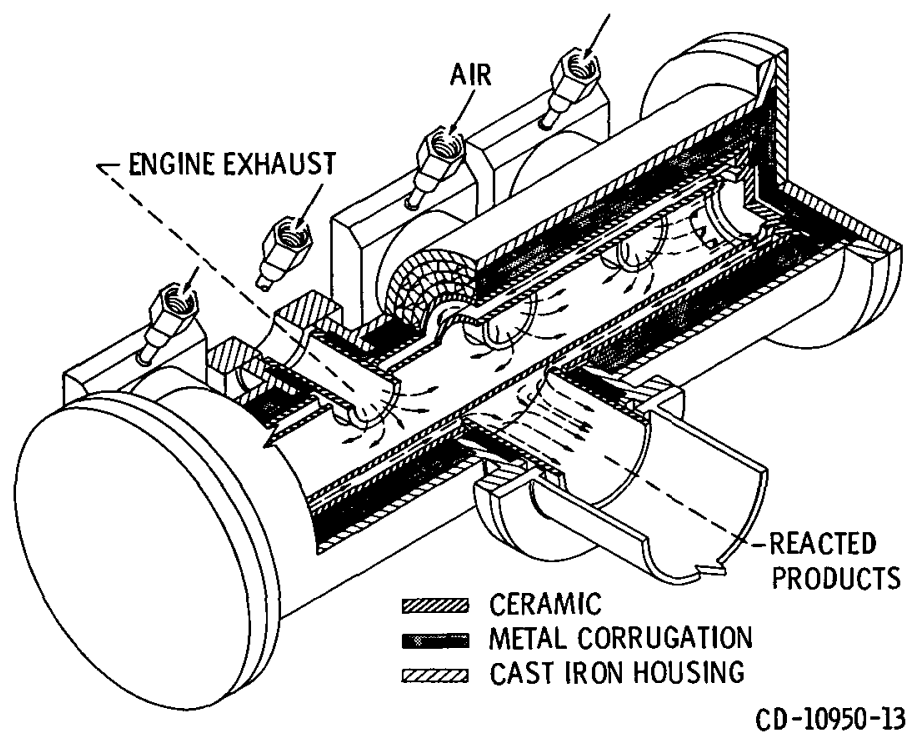

Figure 1. - Ceramic-lined automobile thermal reactor-baseline design.

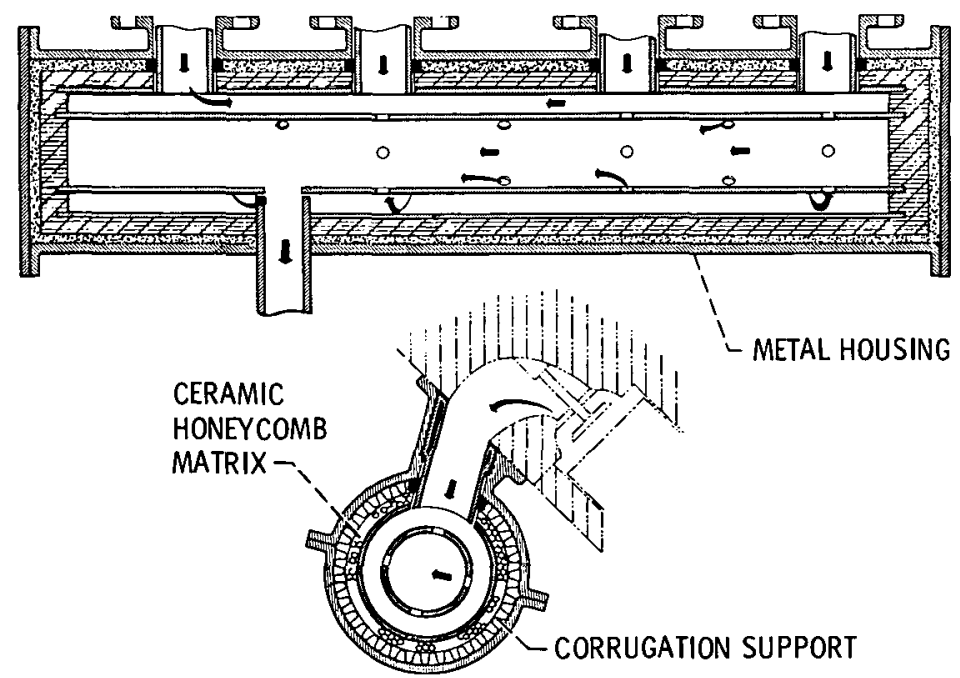

Figure 2. - Glass-ceramic thermal reactor, Owens-Illinois design A. 


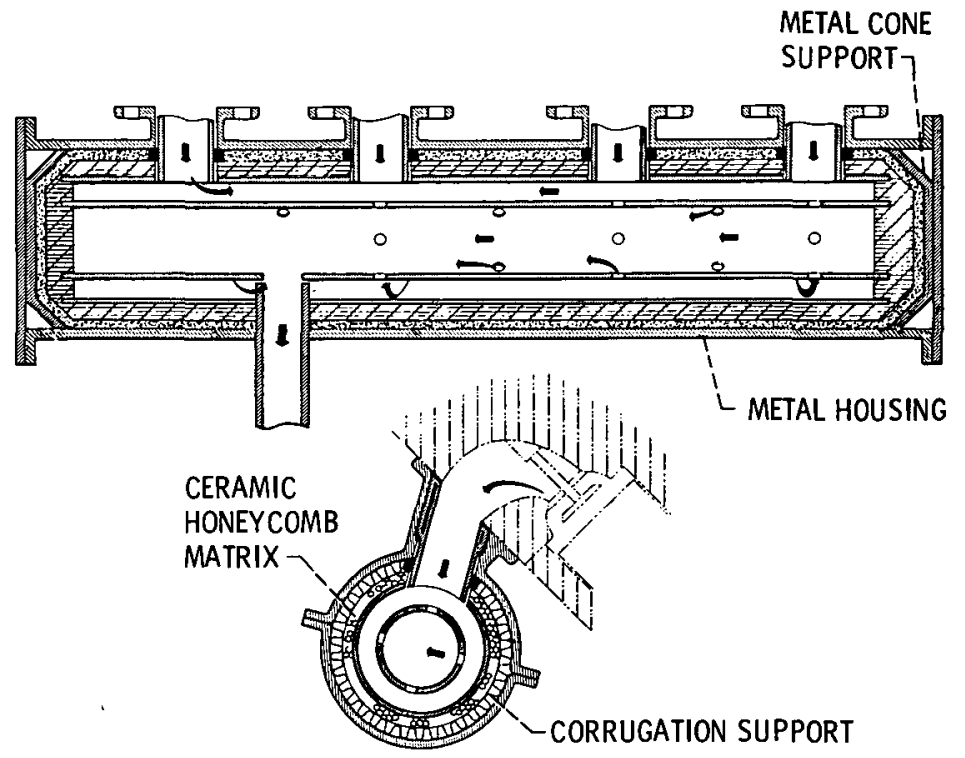

Figure 3. - Glass ceramic thermal reactor, Owens-Illinois design B.
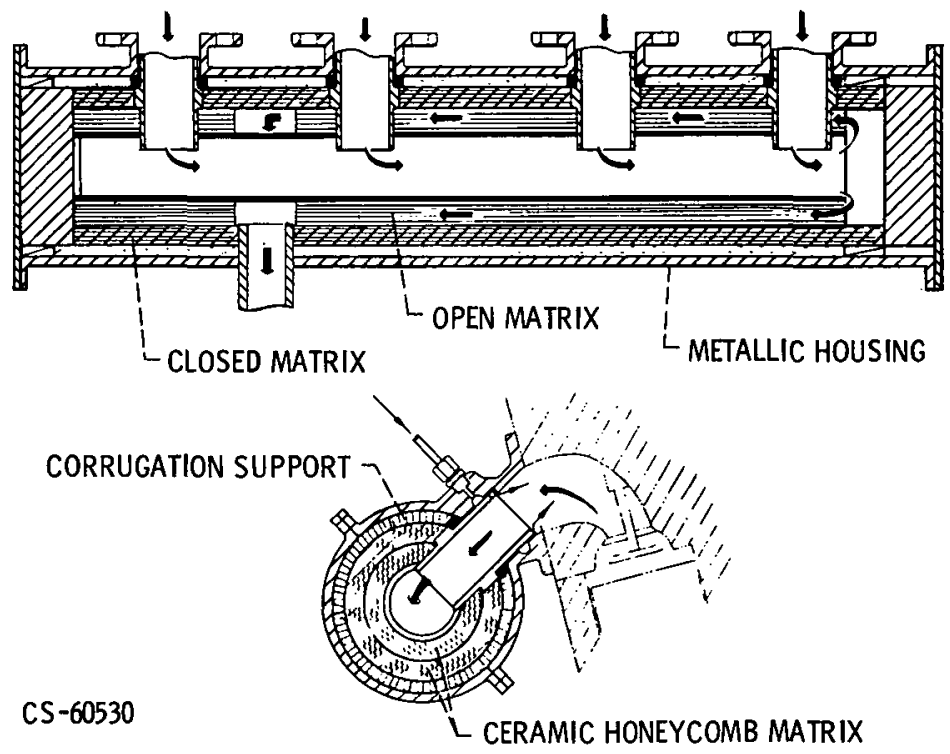

Figure 4. - Glass ceramic thermal reactor, Owens-Illinois design C. 


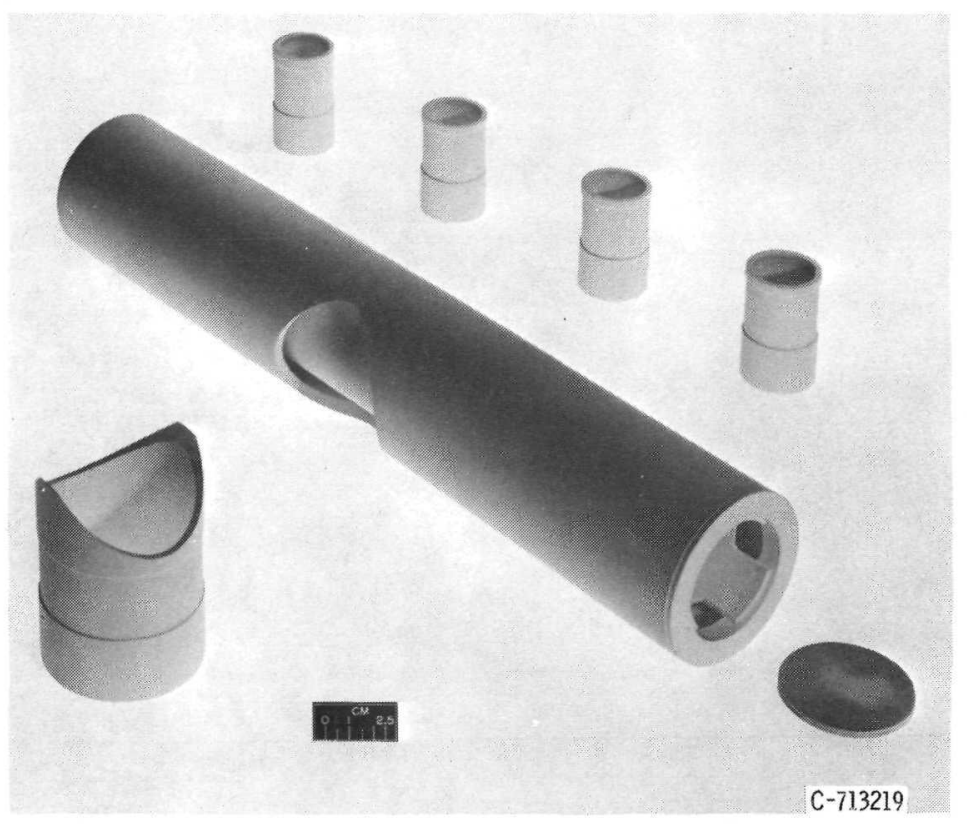

Figure 5. - Glass-ceramic reactor parts prior to assembly into reactor housing.

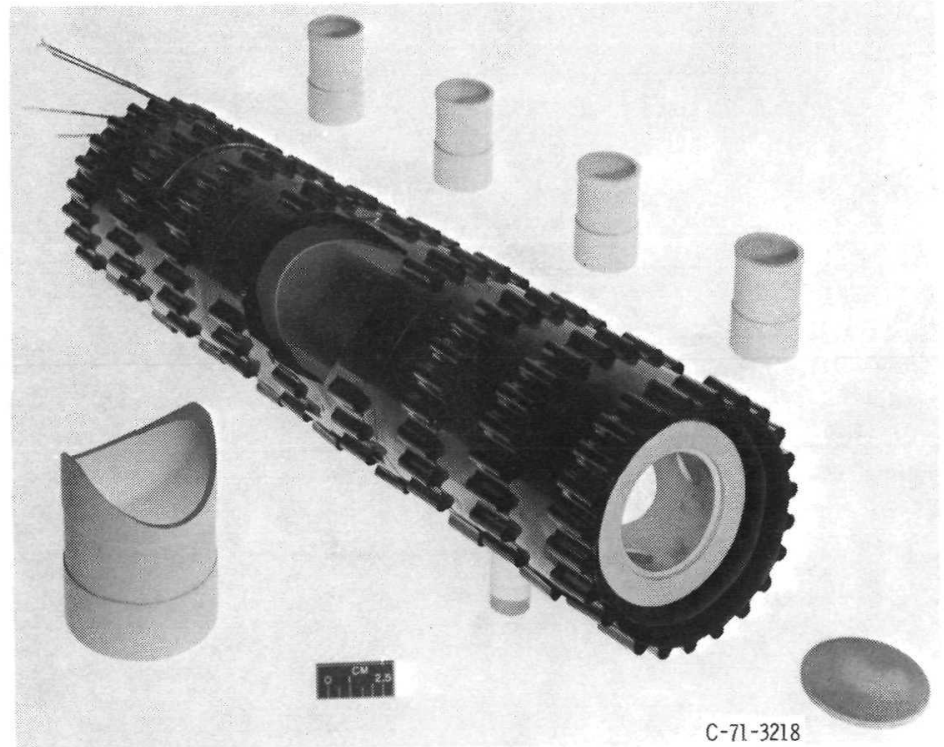

Figure 6. - Glass-ceramic reactor parts with corrugation support structure. 


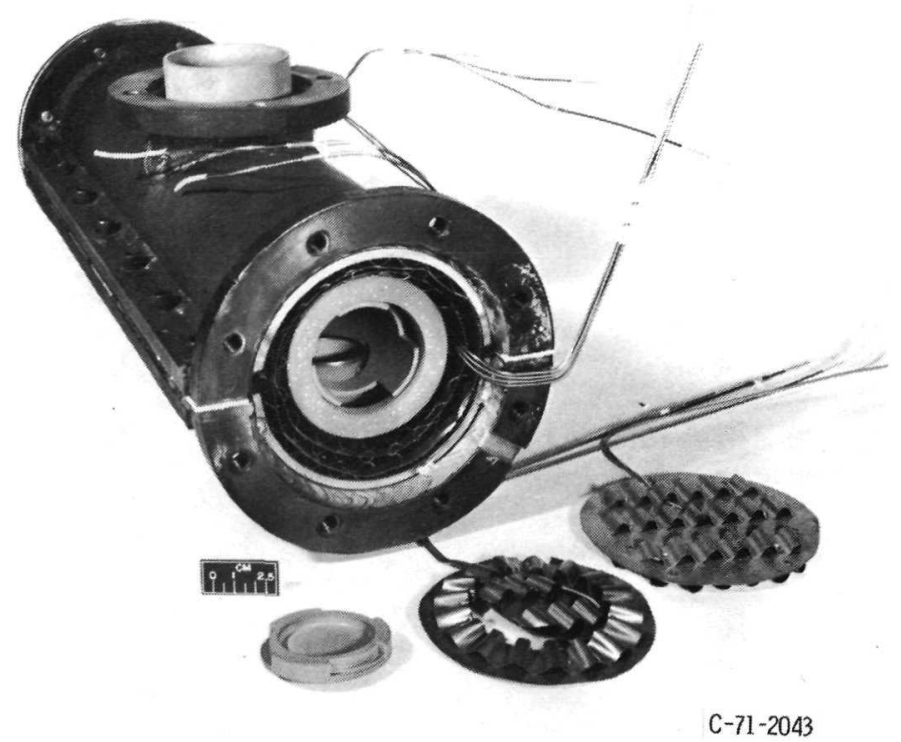

Figure 7. - Final assembly of ceramic thermal reactor-baseline design.

\section{REACTOR \\ TEMPERATURE}

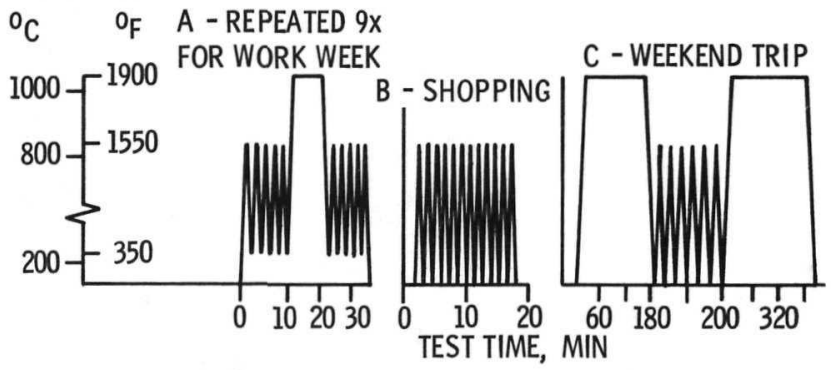

(a) ENGINE-DYNAMOMETER ENDURANCE TEST CYCLE, $A+B+A+C+A+B+A+C$.

COUPON

TEMPERATURE

${ }^{0} \mathrm{C} \quad{ }^{0} \mathrm{~F}$

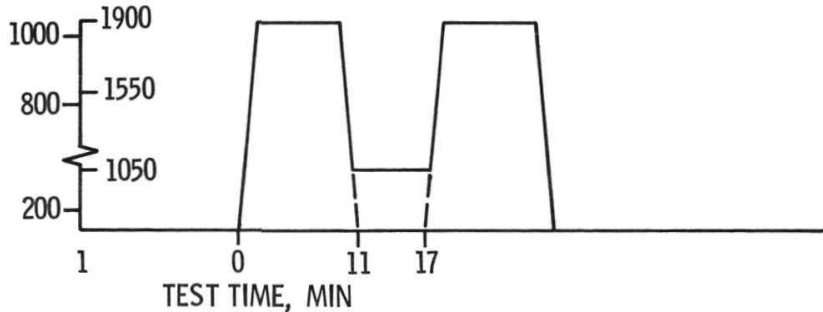

(b) ENGINE-DYNAMOMETER SCREENING TEST CYCLE.

Figure 8. - Engine-dynamometer test cycles. 


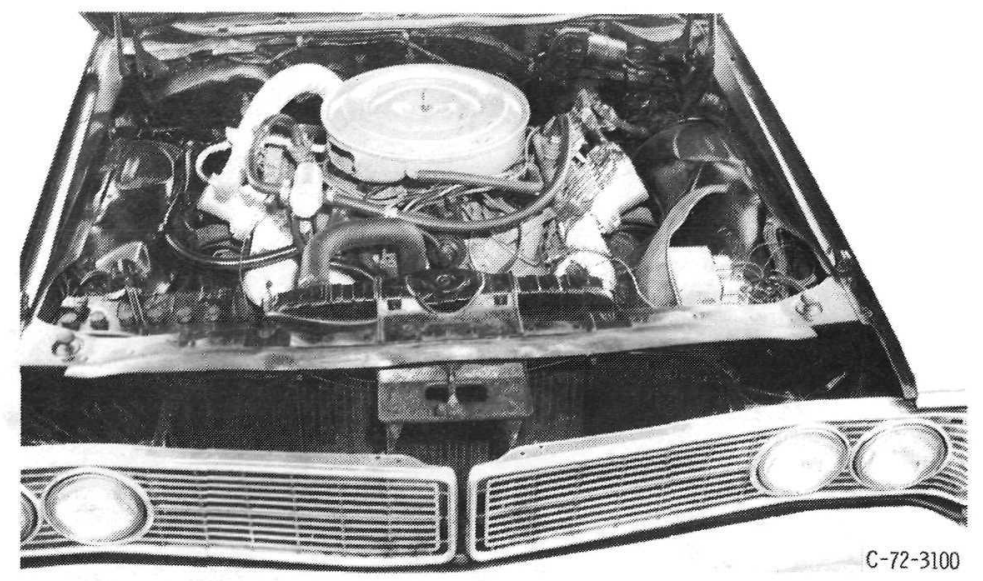

Figure 9. - Engine compartment of test vehicle showing thermal reactor installation.

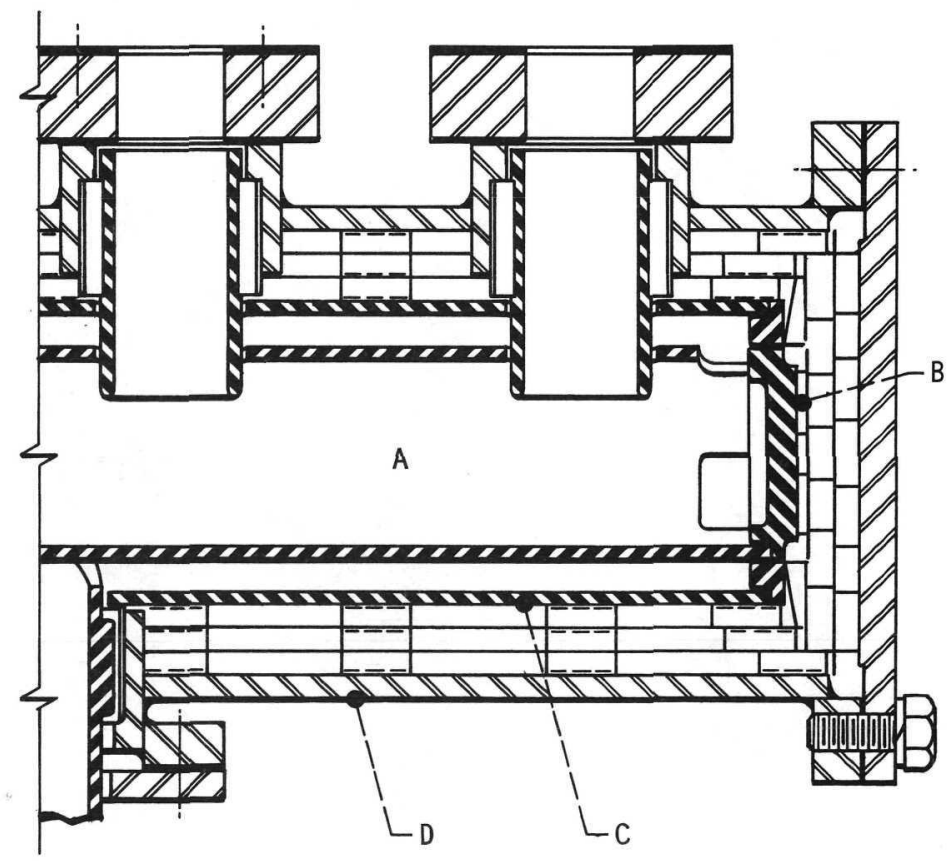

\begin{tabular}{|c|c|c|c|c|c|}
\hline REACTOR MATERIAL & TEST METHOD & $\begin{array}{l}\text { GAS TEMPERATURE, } \\
\qquad{ }^{\circ}{ }^{\circ}\left({ }^{\circ} \mathrm{C}\right)\end{array}$ & 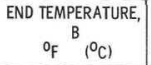 & \begin{tabular}{|c|} 
LINER TEMPERATURE \\
${ }^{\circ} \mathrm{C}$
\end{tabular} & $\begin{array}{l}\text { HOUSING TEMPERATURE, } \\
\left.{ }^{\circ}{ }^{\circ}{ }^{\circ}{ }^{\circ} \mathrm{C}\right)\end{array}$ \\
\hline SILICON CARBIDE & $\begin{array}{l}\text { ENGINE- } \\
\text { DYNAMOMETER }\end{array}$ & $\begin{array}{c}1900-2000 \\
(1040-1090)\end{array}$ & $\begin{array}{l}1200-1400 \\
(700-760)\end{array}$ & $\begin{array}{l}1625-1725 \\
(880-940)\end{array}$ & $\begin{array}{r}900-1000 \\
(480-540)\end{array}$ \\
\hline GLASS-CERAMIC & $\begin{array}{l}\text { ENGINE - } \\
\text { DYNAMOMETER }\end{array}$ & $\begin{array}{c}1900-2000 \\
(1040-1090)\end{array}$ & $\begin{array}{l}925-975 \\
(500-520)\end{array}$ & $\begin{array}{l}1675-1725 \\
(910-940)\end{array}$ & $\begin{array}{r}950-1000 \\
(510-540)\end{array}$ \\
\hline SILICON CARBIDE & ROAD VEHICLE & $\begin{array}{l}1650-1750 \\
(900-950)\end{array}$ & $\begin{array}{l}1400-1450 \\
(760-780)\end{array}$ & $\begin{array}{l}1375-1425 \\
(750-800)\end{array}$ & $\begin{array}{c}375-425 \\
(190-220)\end{array}$ \\
\hline GLASS-CERAMIC & ROAD VEHICLE & $\begin{array}{l}1650-1750 \\
(900-950)\end{array}$ & $\begin{array}{l}1475-1525 \\
(800-830)\end{array}$ & $\begin{array}{l}1475-1525 \\
(800-830)\end{array}$ & $\begin{array}{c}450-500 \\
(230-260)\end{array}$ \\
\hline
\end{tabular}

Figure 10. - Typical reactor temperature profiles - baseline reactor design. 


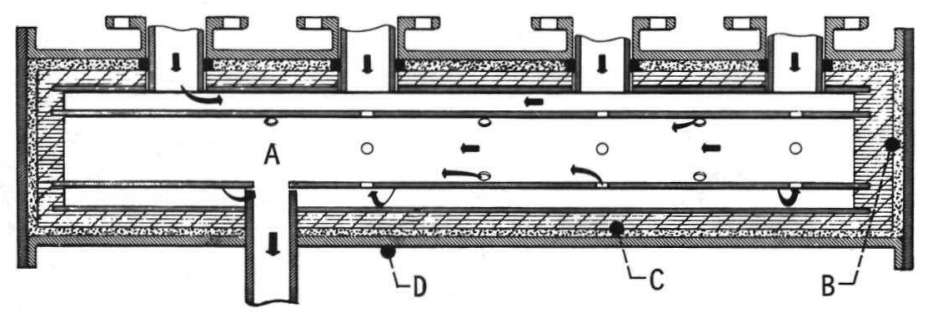

\begin{tabular}{|c|c|c|c|c|}
\hline REACTOR MATERIAL & $\begin{array}{l}\text { GAS TEMPERATURE } \\
\left.{ }^{\circ}{ }^{\mathrm{A}}{ }^{\circ}{ }^{\circ} \mathrm{C}\right)\end{array}$ & $\begin{array}{c}\text { END TEMPERATURE } \\
\left.\qquad{ }^{\mathrm{B}}{ }^{\circ}{ }^{\circ} \mathrm{C}\right)\end{array}$ & \begin{tabular}{|c|} 
LINER TEMPERATURE \\
${ }^{\circ} \mathrm{F}{ }^{\circ}\left({ }^{\circ} \mathrm{C}\right)$
\end{tabular} & $\begin{array}{c}\text { HOUSING TEMPERATURE } \\
\left.{ }^{0}{ }^{\mathrm{D}}{ }^{\circ}{ }^{\circ} \mathrm{C}\right)\end{array}$ \\
\hline GLAS & $\begin{array}{c}1900-2000 \\
(1040-1090)\end{array}$ & $\begin{array}{c}400-500 \\
(200-260)\end{array}$ & $\begin{array}{r}950-1050 \\
(510-570)\end{array}$ & $\begin{array}{l}825-925 \\
(440-500)\end{array}$ \\
\hline
\end{tabular}

Figure 11. - Typical reactor temperature profiles -A, B, and C designs. 